DOI 10.24147/2542-1514.2020.4(2).67-72

\title{
THE LEGAL ISSUES OF THE SUBSTANTIATION OF NEW TYPES OF NATIONAL SECURITY
}

\author{
Anna K. Rozhkova, Irena V. Kochetkova \\ Baikal State University, Irkutsk, Russia
}

\section{Article info}

Received-

2020 January 25

Accepted -

2020 April 15

Available online -

2020 July 03

\section{Keywords}

Security, national security, National security strategy, typology, types of national security, moral security, cultural security
The subject of the article is the typology of national security, and controversial issues of the selection.

The purpose of the article is to identify causes of a large number of security's forms both in theory and in practice, also to analyze acts in this sphere.

The methodology of the article includes analysis, synthesis, formal-legal and comparativelegal methods.

The main results of the research. The author focuses on the problem of types of national security. The author investigates the national security and methodological, theoretical and legal aspects of the classification of national security's forms. The reason for the diversity of types of national security should also be recognized as the lack of a clear classification of them. Author investigates the mechanism for detaching forms of national security in acts of the Russian Federation in the field of security and suggests that new forms of nation security (moral security and culture security) should appear in base document of strategic planning of the national security. Moral security includes cultural, ideological, informational, psychological, scientific, educational, and religious security. Cultural security in its most general form is the stable existence of culture, the protection of this sphere from internal and external threats, for example, such as the emasculation of spiritual and moral values and globalization.

Conclusions. The identification of new types of national security is an objective process due to the very versatility of such a phenomenon as national security. At the same time, it should be recognized that the sphere of spirit and morality in the context of spiritual security does not belong to the legal science, but rather to the field of philosophy and religion. In this regard, their inclusion, even as an adjective, in the text of the strategic planning document raises doubts, so the use of the phrase "moral security" in legal acts in the near future, in our opinion, can hardly be expected. 


\section{Introduction}

The term "security" is used very often today, in different meanings and contexts. In the legal regulation of Russia, there are more than a thousand legal acts that affect the security sphere in one way or another.

Researchers distinguish many types of national security: from traditional ones, such as military or state security, to very exotic ones network and electromagnetic, drug and food security, technological and intellectual security. This is often due to the fact that security in General is a multifaceted phenomenon of legal reality. Such researchers as A. A. Prokhozhev, M. Yu.Zelenkov, N. G. Kutyin, S. V. Khmelevsky, A.V. Shobodoeva and others were engaged in the problem of identifying types of national security and developing classifications. The study of new types of security in theory, in our opinion, is one of the topical issues that have not only doctrinal, but also practical significance.

\section{Types of national security according to the National Security Strategy.}

At the moment, the legislator in paragraph 6 of the National security Strategy of the Russian Federation (hereinafter - the Strategy) identifies 9 types of national security. It is obvious that the generic concept for any of these types will be "national security", although this term should be recognized as a new one.

The legal definition of "national security" was first given in 2000 in the Concept of national security. However, already in the law" on security "of 1992, the first attempt was made to distinguish types of security, with just "security", and not "national security". Article 13 of the law "on security", which has lost its force, mentioned the existence of state, economic, defense, public, information, environmental and other types of security. This clause "and other types of security", in our opinion, has given rise to such an abundance of views about other types of security not specified in the Law.

Federal law No. 390-FZ "On security", adopted on December 28, 2010, which replaced the law of 1992, did not solve the problem of fixing specific types of national security. Thus, according to Art. 1 "the Federal law defines the basic principles and content of activities to ensure the security of the state, public security, environmental security, personal security, and other types of security provided for by the legislation of the Russian Federation", which led to the emergence of new types of security in general, and national security in particular, in legal science after 2010. According to G. A. Atamanov, in theory they are "already about forty" [1].

This contradictory situation existed until December 2015. The new Strategy, approved by presidential decree No. 683 of 31.12.2015, clearly identifies the following types of national security:"state, public, information, environmental, economic, transport, energy, and personal security". Military security is mentioned in paragraph 33 of the Strategy. This list is closed, since it does not imply the turnover of "and others", "and so on", "and others". At the same time, the legislator himself continues to identify new types of security, such as industrial, demographic, radiation, for example, the legal definition of the latter is given in the Federal law "on radiation safety of the population of the Russian Federation". By the way, the phrase "food security" is found in paragraph 23 of the Strategy we have indicated. It is obvious that new types of security are emerging and will continue to emerge in the legal field of the Russian Federation: public relations are changing, the legal reality is changing, and this process should be considered natural.

The reason for the diversity of types of national security should also be recognized as the lack of a clear classification of them. It was stated above that in paragraph 6 of the Strategy, the types of national security are simply listed. A. A. Prokhozhev notes: "any classification should be based on some of the most significant common features. Among them, first of all, it is necessary to distinguish security objects, the nature of threats, and spheres of life" [2]. Thus, depending on the object whose interests are protected from internal and external threats, we can distinguish such types of security as the security of the individual, society, and the state.

Some authors defend the position that the types of national security "are complex system formations that have an internal structure" [3, p.21]. 
For example, within the framework of public security, it is proposed to distinguish "criminological" [4, p.50], "demographic" [5, p. 33], "migration" [6, p. 34], "fire" [7, p. 102], "food" [8] and other types of security as subspecies.

The "classification of types of national security by spheres of life" $[9, p .6]$, in which threats to national security may arise, could be applied. For example, such as: military, information, economic, environmental, transport, and information, while these types of security can be further divided into subspecies.

After analyzing paragraph 6 of the Strategy, it seems that this act mixes at least two classifications of types of national security: by object and by sphere of activity. It is also noteworthy that the 2015 Strategy included energy and transport as separate types of national security, although previously they were not recognized as such in strategic planning documents, despite the fact that the legal definition of the same "transport security" has been known since 2007 .

Thus, we can state the difficulties in justifying the allocation of an independent type of not only "security" itself, but also "national security".

\section{Moral and cultural security.}

Given the formation of various types of security, I would like to point out the need to allocate such types of security as moral and cultural. To date, the legislator does not use these terms. Paragraph 76 of the Strategy refers to the fact that such a direction as ensuring national security in the field of culture is singled out.

At the same time, it seems that the preservation of the history, culture, and language of its people should be one of the priorities of state policy, and they should not just be declared, but actually be provided for. It is fair to recognize the statement of A. F. Nikolsky that: "among the diversity of sides of national security, an important role belongs to the preservation of the identity of the culture and spiritual values of the people" [10, p. 18] and the revival of the national idea.

Paragraph 30 of the Strategy stipulates that one of the national interests of sustainable development in the long term is "the preservation and development of culture, traditional Russian spiritual and moral values", and culture is also a strategic national priority (paragraph 31). Indeed, "in the conditions of rapidly increasing globalization, the state must ensure not only the security of its borders, but also the security of the information and cultural space" [11, p.180]. It is important to preserve and broadcast the need for awareness of one's own identity, which reflects the identity of the Russian people. This circumstance, in turn, serves as the basis for selecting a definition that would reflect cultural, spiritual and moral independence, isolation. Thus, the term "cultural sovereignty" appears in the 2015 Strategy, but the content of this term in legal acts has not yet been disclosed.

It is necessary to note the opinion of scientists in the field of security, for example, Sokolova S. N., Khadzharova M. H., Shubina M. M., Bespalenko P. $\mathrm{N}$., according to which the need is justified not only to introduce into scientific circulation, but also to fix the term "moral security" at the legislative level. Zelenkov believes: "today, when the differences between internal and external means of ensuring national interests and security are blurred, when military power has ceased to be an absolute guarantor of complete security, the prevailing trends towards the integrity and interdependence of the world community force society to take a different view of the problem of ensuring the moral security of the Russian Federation" [12].

The way out of the spiritual crisis, according to Gazgireeva L. H., can be "multi-faceted and purposeful work to ensure moral security" [13, p.14]. Unfortunately, the author does not offer a specific mechanism for ensuring this type of security, believing that "it is based on the fight against lack of spirituality, constant work to assert spirituality in the mind and behavior of a person" [13, ibid.]. In our opinion, we can hardly agree with this conclusion, since the authors believe that spirituality is something national and unique to adherents of Russian culture and the Orthodox religion.however, it is obvious that representatives of other cultures, religions, and beliefs also have high moral qualities, conscience, and a sense of duty.

More specific conclusions were made by $\mathrm{S}$. N. Borisov and A. M. Dmitrakov. This author's team sees moral security as "a set of conditions that ensure the preservation and development of society 
as an independent and self-sufficient moral community" [14]. In addition, they propose to distinguish the following subspecies of moral security: "cultural, ideological, informational, psychological, scientific, educational and religious" [14]. In our opinion, this approach is justified, however, in the modern legal regulation of the Russian Federation, moral security is not considered as a type of national security, so it is premature to distinguish its subspecies.

We should agree with P. N. Bespalenko. He believes that "the introduction of the concept of moral security into scientific circulation is mainly due to the need of the reformed Russian society for stabilization and self-preservation, not only in economic and industrial terms, but also in terms of maintaining and developing national, cultural, and social macro-identity" [15, p. 3]. It is true that the identity of the people is the object of moral security.

At the same time, it should be recognized that the sphere of spirit and spirituality in the context of moral security does not belong to the legal science, but rather to the field of philosophy and religion. In this regard, their inclusion, even as an adjective, in the text of the strategic planning document raises doubts, so the use of the phrase "moral security" in legal acts in the near future, in our opinion, can hardly be expected.

As for cultural security, it should be noted that today there are more than a hundred definitions of culture in the scientific literature, which also makes it difficult to form a legal definition and identify a new type of national security. E. L. Shchukina, in this regard, believes that cultural security is becoming "one of the most important factors of national security, since the problems of preserving and transmitting national cultural values in the modern globalizing world are becoming more acute and important" [16]. Accordingly, the sphere of culture is subject to various threats and challenges "from the rapidly transforming cultural patterns of behavior and life in the world community" [16]. The authors of the article tend to believe that cultural security in its most General form is the stable existence of culture, the protection of this sphere from internal and external threats, for example, such as the
ISSN 2542-1514 (Print)

emasculation of spiritual and moral values and globalization.

\section{Conclusions.}

To sum up, we would like to emphasize once again that the concept of "type of security" is broader in scope than "type of national security", since security and national security are related to each other as a genus and species, respectively. The identification of new types of national security is an objective process due to the very versatility of such a phenomenon as national security. Not so long ago the legislation was recognized as a distinct species of national security, transport and energy, assume that in a short time, to isolate the food and demographic. Thus, in his annual Address to the Federal Assembly of the Russian Federation on January 15, 2020, the President of Russia stressed the priority of preserving the Russian population. It is likely that the problem of security in the field of culture will direct the rule-making not only to formulate a new type of national security, but also to create a new document of strategic planning in this area. 


\section{REFERENCES}

1. Atamanov G.A. Security code. Definitions of the concepts "danger" and "security". Zacita informacii. Inside, 2012, no. 5, p. 8-13. (In Russ.).

2. Prokhozhev A.A. (ed.). The general theory of national security. Textbook. Moscow, RAGS Publ., 2005. 344 p. (In Russ.).

3. Turusov N.A. System of national security of Russia. Yuridicheskaya nauka i praktika: Vestnik Nizhegorodskoj akademii MVD, 2016, no. 3, pp. 20-25. (In Russ.).

4. Savelyev A.I. Criminological security as a type of national security. Vestnik Omskoj yuridicheskoj akademii, 2019, no. 1, pp. 49-54. (In Russ.).

5. Karmanov M.V., Korotkov A.V. Modern problems of financial provision of demographic security in Russia. Statistika i ekonomika = Statistics and Economics, 2011, no. 4, pp. 33-36. (In Russ.).

6. Nazarov M.V. Migration security: concept, essence, principles. Vestnik Moskovskogo universiteta MVD, 2016, no. 8, pp. 32-36. (In Russ.).

7. Karasev A.T., Makarkin S.V. Fire security - a type of public security in Russia (legal and theoretical aspects). Vestnik Yuzhno-Ural'skogo gosudarstvennogo universiteta. Seriya: Pravo = Bulletin of the South Ural State University. Series "Law", 2015, no. 3, pp. 102-107. (In Russ.).

8. Belkharoev H.U. The role of food security in the general legal system of national security. Biznes $v$ zakone, 2009, no. 3, p. 165-167. (In Russ.).

9. Shobodoeva A.V. Theory of national security of the Russian Federation. Textbook. Part 2. Irkutsk, BGU Publ. House, 2017. 307 p. (In Russ.).

10. Nikolskiy A.F. Theory of sustainable development and issues of global and national security. Irkutsk, Sibirskaya kniga Publ., 2012. 358 p. (In Russ.).

11. Rozhkova A.K. Cultural sovereignty in the context of national security, in: Meteleva E.R. (ed.). Materialy Mezhdunarodnogo Bajkal'skogo foruma Konferencii «Evrazijskij integracionnyj proekt: civilizacionnaya identichnost' i global'noe pozicionirovanie». Irkutsk, BGU Publ., 2018. pp. 279-282. (In Russ.).

12. Zelenkov M.Yu. Moral security of the Russian Federation: problems and solutions. Available at: http://zelenkov.ucoz.ru/publ/dukhovnaja_bezopasnost_rossijskoj_federacii_problemy_i_puti_reshenija/1-1-0-2 (date of access: 15.01.2020) (In Russ.).

13. Gazgireeva L.H., Burnyasheva L.A. Existential foundations of spiritual security of the Russian society. Vlast', 2011, no. 2, pp. 11-15. (In Russ.)

14. Borisov S.N., Dmitrakov A.D. Spiritual security and security problems in the modern world. Nauka. Iskusstvo. Kul'tura, 2018, no. 3, p. 42-48. (In Russ.)

15. Bespalenko P.N. Spiritual security in the national security system of modern Russia: problems of institutionalization and solution models. Doct. Diss. Thesis. Rostov-on-Don, 2010. 54 p. (In Russ.).

16. Shchukina E.L. Cultural security of modern Russia as an element of national security. Gosudarstvennoe i municipal'noe upravlenie. Uchenye zapiski SKAGS = State and Municipal Management Scholar Notes, 2015, no. 3, p. 346-350. (In Russ.).

\section{INFORMATION ABOUT AUTHORS}

Anna K. Rozhkova - Graduate Student, Institute of State and Law

Baikal State University

11, Lenina ul., Irkutsk, 664003, Russia E-

mail:rannette@mail.ru

Irena V. Kochetkova - Senior Lecturer, Department

of Legal Support of National Security

Baikal State University

11, Lenina ul., Irkutsk, 664003, e-

mail:irenako88@gmail.com 


\section{BIBLIOGRAPHIC DESCRIPTION}

Rozhkova A.K., Kochetkova I.V. The legal issues of the substantiation of new types of national security.

Pravoprimenenie = Law Enforcement Review , 2020, vol. 4, no. 2, pp. 67-72. DOI: 10.24147/2542-1514. 2020.4(2).67-72. (In Russ.). 